Tecnología y

Ciencias $\stackrel{\varpi}{\unlhd}$ gua
2019, Instituto Mexicano de Tecnología del Agua Open Access, license CC BY-NC-SA 4.0

(https://creativecommons.org/licenses/by-nc$\mathrm{sa} / 4.0 /$ )

DOI: $10.24850 /$ j-tyca-2019-03-08

Articles

\title{
Experimental and analytical investigation of secondary current cells effects on hydraulic jump characteristics in trapezoidal channels
}

\section{Investigación experimental y analítica de los efectos de las células secundarias actuales en las características del salto hidráulico en canales trapezoidales}

Bahador Fatehi Nobarian ${ }^{1}$

Hooman Hajikandi ${ }^{2}$

Yousef Hassanzadeh ${ }^{3}$

Saeed Jamali ${ }^{4}$

${ }^{1}$ Ph.D. Candidate, Department of Civil Engineering, Faculty of

Engineering, Islamic Azad University- Tehran Central Branch, Tehran, Iran, bahadorfn@yahoo.com

${ }^{2}$ Assistant Professor, Department of Civil Engineering, Faculty of Engineering, Islamic Azad University-Tehran Central Branch, Tehran, Iran, h_hajikandi@iauctb.ac.ir

${ }^{3}$ Professor of Faculty of Civil Engineering, University of Tabriz, Tabriz, Iran, yhassanzadeh@tabriz.ac.ir

${ }^{4}$ Assistant Professor, Department of Civil Engineering, Faculty of Engineering, Islamic Azad University-Tehran Central Branch, Tehran, Iran, sae.jamali@iauctb.ac.ir

Correspondence author: Hooman Hajikandi, h_hajikandi@iauctb.ac.ir

\section{Abstract}

Fluid dynamics aims at understanding the movement of liquids and gases by functions that describe the distribution of velocities. In the present study, the characteristics of secondary currents in trapezoidal channels with side angles of 45,60 and $75^{\circ}$ subjected to the influence 
of five different discharges with experimental tests, are investigated and the results are compared with that of Flow3D. The results obtained from experimental measurements and numerical models comparison of the rate of secondary currents in different Froude numbers demonstrated that there exists an opposite relationship between the secondary velocity in the direction of perpendicular to the axis of flows $\left(V_{x}\right)$ and velocity in a direction perpendicular to the flow level $\left(V_{z}\right)$ in trapezoidal channels. Moreover, at $45^{\circ}$ angle, there has been a remarkable energy loss during hydraulic jump. The ratio of the increase in the secondary currents velocity in $X$ direction in Froude number 10 of $45^{\circ}$ angle is higher than that of two other sections, which is equal to $71 \%$, compared to $75^{\circ}$ angle in numerical models and in Froude number 9 it was $91 \%$ during experimental tests. Then, the secondary currents velocity in Z direction for Froude number 2 of $75^{\circ}$ angle is higher than that of two other sections, which is $88 \%$, compared to the $45^{\circ}$ angle in numerical models and in Froude number 1.5 it was equal to $74.5 \%$ for experimental tests.

Keywords: Secondary currents, trapezoidal channel, hydraulic jump, boundary shear stress.

\section{Resumen}

La dinámica de fluidos tiene como objetivo comprender el movimiento de líquidos y gases mediante funciones que describen la distribución de velocidades. En el presente estudio se investigan las características de las corrientes secundarias en canales trapezoidales con ángulos laterales de 45,60 y $75^{\circ}$ sometidas a la influencia de cinco descargas diferentes con pruebas experimentales; los resultados se comparan con los de Flow3D. Los resultados obtenidos de las mediciones experimentales y la comparación de modelos numéricos de la velocidad de las corrientes secundarias en diferentes números de Froude demostraron que existe una relación opuesta entre la velocidad secundaria en la dirección perpendicular al eje de flujos $\left(V_{x}\right)$ y la velocidad en una dirección perpendicular al nivel de flujo $\left(V_{z}\right)$ en canales trapezoidales. Además, a un ángulo de $45^{\circ}$, ha habido una pérdida de energía notable durante el salto hidráulico. La relación del aumento en la velocidad de las corrientes secundarias en la dirección $X$ en Froude número 10 de ángulo de $45^{\circ}$ es mayor que la de otras dos secciones, que es igual a $71 \%$, en comparación con el ángulo de $75^{\circ}$ en modelos numéricos; en Froude número 9 fue de $91 \%$ durante las pruebas experimentales. Luego, la 
Ciencias
2019, Instituto Mexicano de Tecnología del Agua Open Access, license CC BY-NC-SA 4.0

(https://creativecommons.org/licenses/by-nc$\mathrm{sa} / 4.0 /$ )

velocidad de las corrientes secundarias en la dirección $Z$ para Froude número 2 de $75^{\circ}$ ángulo es mayor que la de otras dos secciones, que es $88 \%$, en comparación con el ángulo de $45^{\circ}$ en modelos numéricos y en Froude número 1.5 fue igual a $74.5 \%$ para pruebas experimentales.

Palabras clave: corrientes secundarias, canal trapezoidal, salto hidráulico, tensión de cizallamiento límite.

Received: $31 / 07 / 2018$

Accepted: $13 / 12 / 2018$

\section{Introduction}

One of the most frequently encountered cases of rapidly varied flow is the hydraulic jump phenomenon. The most important application of the hydraulic jump is in the dissipation of energy below spillways, weirs, gates, etc. Based on 3-D observations during experimental tests, the flow phenomena significantly differs from the classical hydraulic jump in trapezoidal and rectangular channels. The most extensively studied case of the hydraulic jump is in horizontal rectangular channels and detailed metric discussion. The schematic sketch of a typical hydraulic jump in a horizontal channel is depicted by Figure 1 . The hydraulic jump and its steadiness in the trapezoidal channel are especially important. Scholars, such as Wanoschek and Hager (1989) and Muhsun (2012) analyzed the properties of trapezoidal channels through experimental tests. Hager (1992) and Chanson (2007) studied the undular hydraulic jump, and they described its characteristics where the values of the Froude number in which the jump is no longer than undular was calculated regardless of the effect of the channel width. Afzal and Bushra (2002) studied structure of turbulent hydraulic jump in trapezoidal channel. 


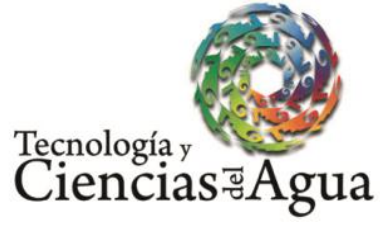

2019, Instituto Mexicano de Tecnología del Agua Open Access, license CC BY-NC-SA 4.0

(https://creativecommons.org/licenses/by-nc$\mathrm{sa} / 4.0 /)$

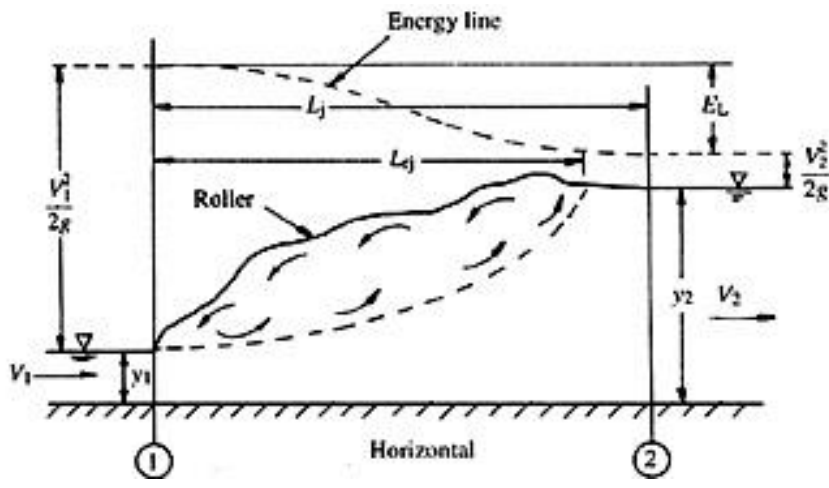

Figure 1. Hydraulic jump flow structure.

The surface profile approaches as limiting universal solution provided that the variables are appropriately non-dimensionalized. Gupta, Mehta and Dwivedi (2013) investigated relative length and relative energy loss of free hydraulic jump in prismatic channels. Ohtsu (1976) classified the hydraulic jumps in trapezoidal channels into four types. The criterion involved the symmetry of the main current. Ohtsu (1976) recommended that only hydraulic jumps of types 1 and 2 ("the jump is almost symmetric") should be used as the energy dissipater. Kim, Choi, Park and Byeon (2015) has investigated hydraulic jump properties and it's energy dissipation in downstream with sluice gate. Javan and Eghbalzadeh (2013) has studied submerged hydraulic jump with k- $\varepsilon$ turbulent modeling. Nezu et al. (1985) after studying the effect of roughness on experimental results in rectangular canal, even when boundary roughness conditions change, showed that the main structure of secondary currents does not change dramatically. Yaaghoubi and Givechi (2007) investigated the effect of secondary currents in the average velocity of cross sections in rectangular channels. After studying the effect of roughness on experimental results in rectangular channel, even when boundary roughness conditions change, the main structure of secondary currents does not change dramatically. Nezu, Nakagawa and Tominaga (1985), and Qin, Shao and Zhou (2016) made a comparison between two different secondary current correction moles for depth-averaged flow of meandering channels. Investigation of the distribution of boundary shear stresses in prismatic trapezoidal channels has also been studied by other researchers, including Dasgupta and Tomar (2015). Shokrian-Hajibehzad and Shafai-Bejestan (2017) predicted sequent depth ratio in hydraulic jump on river and the sequent depth ratio on rough rocky beds was found to be considerably smaller 
Tecnología y

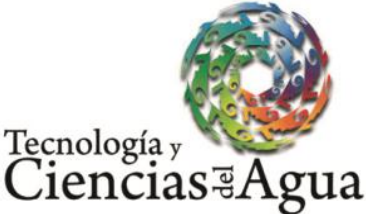

2019, Instituto Mexicano de Tecnología del Agua Open Access, license CC BY-NC-SA 4.0 (https://creativecommons.org/licenses/by-nc$\mathrm{sa} / 4.0 /$ )

than those on a smooth concrete bed. Two new prediction equations, for smooth and rough bed slopes, are presented and the results showed that the predictions agree reasonably well with the experimental data.

Jalili-Ghazizadeh, Attari and Farhadi-Rad (2017) studied the hydraulic jump alongside weirs. In the model, the lateral outflow momentum is considered in which the model predicts the location of the hydraulic jump. Present study seeks to fill the research gap related to the investigation of secondary current cells in trapezoidal channels and their effect on hydraulic jump phenomenon which should be considered as the novelty of the research.

The present paper pursues two main objectives, including 1) the characteristics and properties of secondary currents in hydraulic jump for trapezoidal channels incorporating three various side slope angles (lateral angles) using both experimental and numerical approaches and 2) variation in energy loss in hydraulic jump relative to changes in Froude numbers for both experimental and numerical analyses, as well as comparison with findings obtained by Hager (1992). The main focus of the study is concentrated on different trapezoidal sections subjected to various flows discharge.

\section{Secondary current cells}

Generally, secondary currents are a subset of flows in the cross sections or around the axis perpendicular to the cross section of the flow. The currents in curves are called strong secondary currents, but those in prismatic channels of the plan are called weakly secondary currents. Secondary currents and open channels are significantly important in hydraulic engineering, due to the immense effect of these currents on the flow field, the impact of the friction rule and the formation of threedimensional shapes on the beds of the channels. 


\section{Secondary currents equations}

The main purpose for making secondary currents in a uniform longitudinal flow is the uniformity of the Reynolds stress disparity and, essentially, its vertical components. Prandtl (1904) dictated the two main mechanisms leads to rotational flows in the flow direction, namely, 1 -deviation of the main shear stresses by a lateral pressure gradient or physical force, and 2-inconsistency and fluctuating turbulence in a plate perpendicular to the rotation axis. The longitudinal rotational equation in the fully developed turbulent flow is subrogated (Azhdari-Moghaddam, Tajnasaj, \& Givech, 2013):

$$
\begin{aligned}
& V \frac{\partial \xi}{\partial y}+W \frac{\partial \xi}{\partial z}=\frac{\partial^{2}}{\partial y \partial z}\left(\bar{v}^{2}-\bar{w}^{2}\right)+ \\
& \left(\frac{\partial^{2}}{\partial z^{2}}-\frac{\partial^{2}}{\partial y^{2}}\right) \overline{v w}+\vartheta\left(\frac{\partial^{2}}{\partial y^{2}}-\frac{\partial^{2} \xi}{\partial z^{2}}\right) \\
& \xi=\frac{\partial v}{\partial z}-\frac{\partial \mathrm{w}}{\partial \mathrm{y}}
\end{aligned}
$$

Where $\mathrm{W}$ and $\mathrm{V}$ refers to velocity components in horizontal direction ( $\mathrm{Z})$, and velocity components in vertical direction $(Y)$, respectively.

In fact, these are the same secondary current components; where $\vartheta$ is kinematic viscosity of fluid, $-\overline{\mathrm{VW}}$ denotes Reynolds shear stress. $\overline{V^{2}}$ and $\overline{\mathrm{W}^{2}}$ refer to Reynolds normal stress. That is indicated by the flow function:

$$
v=\frac{\partial \psi}{\partial y} \quad, \quad w=\frac{\partial \psi}{\partial z}
$$

Figure 2 illustrates the difference of vertical stresses in the main structure of the secondary flows. 

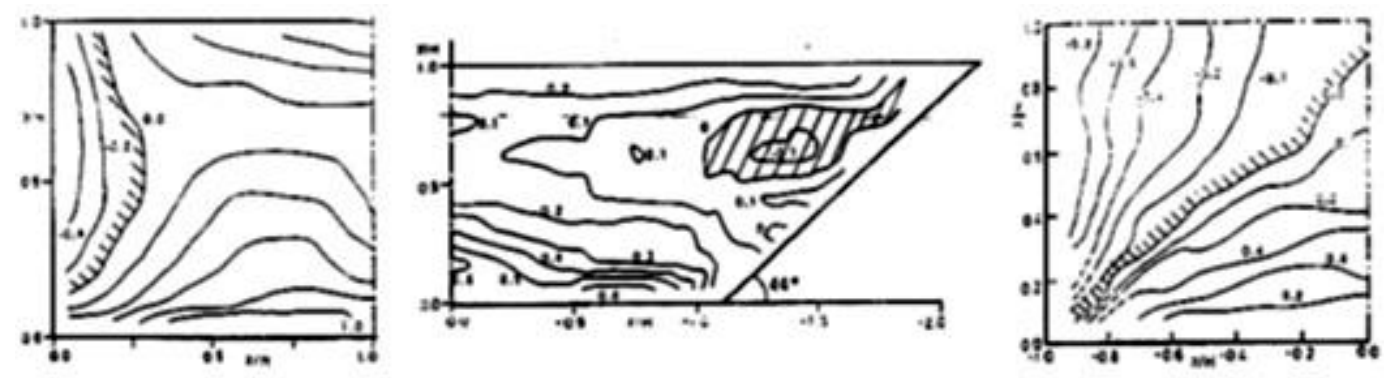

Figure 2. Non-dimensional lines $\left(\overline{\mathrm{W}}^{2}-\overline{\mathrm{V}}^{2}\right) / \mathrm{U}^{2} \max$ from right in the order of closed channel, trapezoidal channel, and rectangular channel.

In the present work, variables $Z$ and $Y$ are in the order of $X$ for velocity perpendicular to the flow axis and $Z$ for velocity perpendicular to the channel bed. The following equation shows the hydraulic jump phenomenon in the current study as investigated based on the definition of rotational flows, so that curl is function in flow opposite to zero:

$\vec{\nabla} \times \vec{U}=\left|\begin{array}{ccc}\mathrm{i} & \mathrm{j} & \mathrm{k} \\ \frac{\partial}{\partial \mathrm{x}} & \frac{\partial}{\partial \mathrm{y}} & \frac{\partial}{\partial \mathrm{z}} \\ \mathrm{Ux} & \mathrm{Uy} & \mathrm{Uz}\end{array}\right|=\varepsilon \mathrm{ijk} \partial \mathrm{j} \mathrm{jk} \neq 0$

Where $\vec{\nabla}$ represents Nebula operator calculated as follows in the Cartesian system.

$\vec{U}$ is velocity component:

$\vec{\nabla}=i \frac{\partial}{\partial x}+j \frac{\partial}{\partial y}+k \frac{\partial}{\partial z}$

Flow-3D modeling 
Solving the CFD (Computational Fluid Dynamic ) problem usually consists of four main components: geometry and grid generation, physical model set up, solution and the post-process of the computed data. The set problem is computed to generate the geometry and grid, and the data are acquired in a well-known manner. The modeling of a phenomenon involves complex problems which can be resolved by developing a simple model. Therefore, while an ideal model should introduce the minimum amount of complexity into the modeling equations, it is important to be as accurate as possible. To conduct a numerical model of the secondary currents, initially, it is necessary to develop a numerical model of the mean velocity indifferent sections for obtaining the limits of a velocity change in a proper manners.

According to Bayon, Valero, García-Bartual and López-Jiménez (2016) the boundary value for the quantities $\mathrm{K}_{\mathrm{T}}$ and $\varepsilon_{\mathrm{T}}$ are usually assumed to determine the local equilibrium between the processes of production and decay of turbulent shear stress and a rule of wall velocity profile. In this research, the RNG (Renormalization Group) model was used due to its statistical methods for deriving average equations for disturbance quantities such as kinetic energy and its loss rate making it the best turbulence model for simulating a hydraulic jump. The flow-3D software is employed to obtain an accurate correlation between the solution and the convergence of responses, which are based on the geometric spectral flow and flow characteristics (Microsoft Corporation, 2015).

\section{ADV signal correlation}

Extensive explanations on ADV (Acoustic Doppler Velocimeter) principles of operation can be found in Nortek Operational Manual (Nortek-AS, 2013). The velocities are estimated by using a technique called a pulse coherent Doppler processing, where the ADV measures the change in phase of the return signal from two successive acoustic pulses. The acoustic return is not a reflection from a single target, but a superposition of the reflections from many individual particles contained in the sampling volume. A phase coherency is achieved if all particles in 
the sampling volume maintain their relative positions concerning each other, in which case the strength and relative phases of individual reflections would not change from one pulse to the next. However, Doppler noise is an inherent part of Doppler-based volume backscatter systems, and there are other sources of noise as well. Thus, the return signal from the second pulse is not a phase-shifted reproduction of the first pulse, but it contains a certain amount of noise, which can be added to the coherent part of the return signal (Nortek-AS, 2013):

$S_{1}^{\prime}=S_{1}+N_{1}$

$S_{2}^{\prime}=S_{2}+N_{2}$

Where $\mathrm{S}^{\prime}$ and $\mathrm{S}^{\prime}$ are the return signals from two adjacent pulses, $\mathrm{S}_{1}$ and $S_{2}$ are the coherent parts of the signal, and $N_{1}$ and $N_{2}$ represent the random noise. In practice, the ADV estimates the phase shift between return signals from two successive pulses using a complex autocorrelation function, which has a phase and a magnitude. The phase is proportional to the distance which is traveled in the time between pulses by scatters, and thus to the velocity. The magnitude is a measure of how similar the echoes from two return signals are, and the normalized magnitude yields the correlation coefficient. If the echoes from two neighboring pulses were identical and only with a phase change, the correlation would be perfect and equal to $100 \%$. As the echoes become more dissimilar, the correlation decreases. Low correlations are associated with highly turbulent flows, air bubbles in the flow, low SNR (Signal to Noise Ratio) values, large velocity gradients within the sampling volume, the presence of large individual particles, or interference from the boundary.

In turbulent flows such as hydraulic jump, it is reasonable to assume that the particles in the sample volume will not maintain their relative positions concerning each other, thus the Doppler noise of the return signal will be added. This will decorrelate the signal, and in this case low signal correlations will not necessarily mean that the data is undesirable. Also, if the turbulence eddies are of the same order as the sample volume or smaller, the correlation will change even more, which will lead to increase of the noise in velocity measurements. The correlation 
Tecnología y

Ciencias $₫$ Agua
2019, Instituto Mexicano de Tecnología del Agua Open Access, license CC BY-NC-SA 4.0

(https://creativecommons.org/licenses/by-nc$\mathrm{sa} / 4.0 /$ )

coefficient for turbulent flows will be discussed in more detail in the next section.

\section{Experimental study}

To create a hydraulic jump along the channel, several hydraulic modes have been tested in the laboratory model. Previous studies examined the classical jumps made for rectangular cross-sections. The experimental set-up and properties of channel are presented in Table 1.

Table 1. Geometric characteristics of channel.

\begin{tabular}{|c|c|c|c|c|c|}
\hline Type of channel & $\begin{array}{c}\text { Length } \\
\text { (m) }\end{array}$ & $\begin{array}{c}\text { Width } \\
\text { (m) }\end{array}$ & $\begin{array}{c}\text { High of side } \\
\text { wall } \\
\text { (m) }\end{array}$ & $\begin{array}{c}\text { Valve } \\
\text { Opening } \\
(\mathrm{m})\end{array}$ & $\begin{array}{c}\begin{array}{c}\text { Location of } \\
\text { Valve }\end{array} \\
\text { (m) }\end{array}$ \\
\hline$m=1.0$ & \multirow{3}{*}{5} & \multirow{3}{*}{0.2} & \multirow{3}{*}{1} & \multirow{3}{*}{0.035} & \multirow{3}{*}{0.2} \\
\hline$m=0.58$ & & & & & \\
\hline$m=0.26$ & & & & & \\
\hline
\end{tabular}

Where $\mathrm{m}$ is the side slope of the channel and it is schematically represented in Figure 3. The numerical value of the side slope for angles $45^{\circ}, 60^{\circ}$ and $75^{\circ}$ in this investigation was equal to $1.0,0.58$ and 0.26 , respectively.

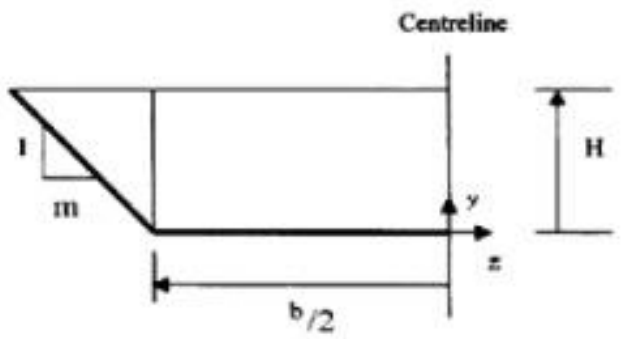


Tecnología y

Ciencias $\approx$ Agua
2019, Instituto Mexicano de Tecnología del Agua

Open Access, license CC BY-NC-SA 4.0

(https://creativecommons.org/licenses/by-nc$\mathrm{sa} / 4.0 /)$

Figure 3. Side slope in half cross-sectional.

The volume of reservoir tank of beginning of the channel is $3.2 \mathrm{~m}^{3}$. Figure 4 and Figure 5 show Geometry characteristics of the channel and position of the ADV on the channel.

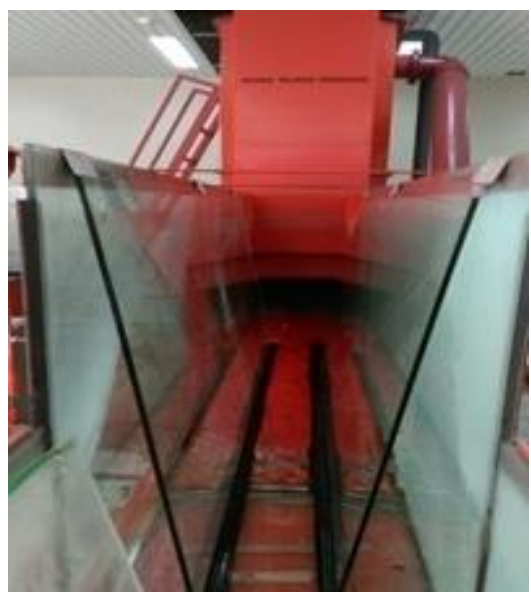

Figure 4. Geometry of trapezoidal channel at three angles.

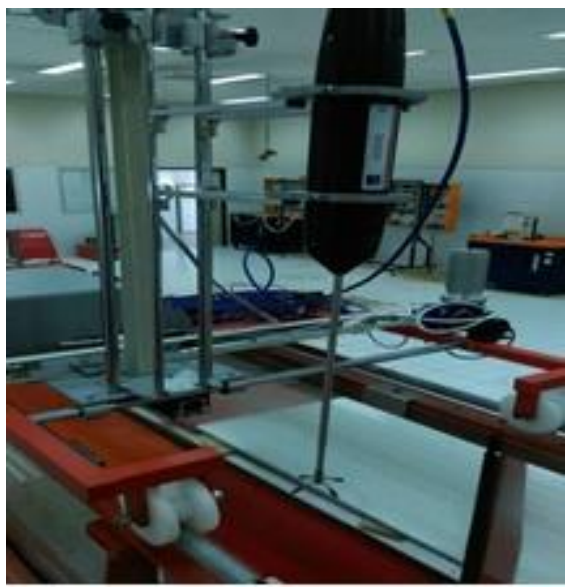

Figure 5. Device ADV specifications on the channel.

As shown in Figure 5, the ADV machine is mounted on a carriage, it moves on the channel using (Jog) software and sends the device to the designated depth at the desired location. In this paper, the 
measurements were carried out at $25 \mathrm{~Hz}$ for 2 minutes, with a total of 3000 impressions for the average point velocity ( $u, v, w)$.

Based on previous experience, the device is initially completely resting in laminar flow, so that the device can send the frequency inside the flow, then, lower discharge was used to harvest secondary velocities at the beginning of a hydraulic jump. The discharges used in this study were equal to $10,30,50,70$ and $90 \mathrm{lit} / \mathrm{s}$, for three sectional geometry angles, including 45,60 and $75^{\circ}$ angles in trapezoidal channel.

The point that matters in Victorina ${ }^{+}$software settings is that all values in the configuration of the trial and error must match in a coordinated manner obtained for all four recipients that the correlation coefficient must be greater than $70 \%$ and the SNR must be greater than $15 \mathrm{~dB}$ (Martin, Fisher, Millar, \& Quick, 2002). In the present study, the numerical value of SNR $23 \mathrm{~dB}$ to $24 \mathrm{~dB}$ is obtained.

It should be noted that the correlation coefficient is a parameter for determining the quality of the measurement of velocity in percent. In each measurement, the device calculates the correlation parameter for each audio receiver. The $100 \%$ correlation value at best indicates a low noise measurement and a zero correlation indicates the effect of noise reduction due to noise. Ideally, measurements should correlate $70 \%$ and $100 \%$. Also, SNR is signal to noise ratio and the amount of this parameter in the measurements is indicative of the presence of sufficient particles in the water to disperse the sound. If the water is very clear and smooth, the return signal to the device receptors is weak, compared to the existing noise and the device will not be able to measure the velocity. During the measurement of turbulent flows such as hydraulic jumps, this ratio should not be lower than 15 . In the present research, the pumps were used to determine the desired discharge in the channel. About Table 2, the state of pumps rpm is ready for realization of different discharges. It is worth noting that during the test, three pumps were utilized, in such a way that all other discharges were formed by combining two or three pumps, expect for the values of first two discharges.

Table 2. The status of the ultrasonic pumps

\begin{tabular}{|c|c|c|c|}
\hline Row & Type of pump & $\begin{array}{c}\text { Round per minute } \\
\text { (RPM) }\end{array}$ & Q (I/s) \\
\hline 1 & Constant discharge & 1754 & 33 \\
\hline
\end{tabular}


Tecnología y

Ciencias $\approx$ Agua
2019, Instituto Mexicano de Tecnología del Agua Open Access, license CC BY-NC-SA 4.0 (https://creativecommons.org/licenses/by-nc$\mathrm{sa} / 4.0 /$ )

\begin{tabular}{|c|c|c|c|}
\hline 2 & \multirow{5}{*}{ Variable discharge } & 4783 & 90 \\
\hline 3 & & 3507 & 70 \\
\hline 4 & & 2659 & 50 \\
\hline 5 & & 1576 & 30 \\
\hline 6 & & 896 & 10 \\
\hline
\end{tabular}

The Vectrino device measures water velocity based on the Doppler phenomenon. Based on this phenomenon, if the audio source moves at $\mathrm{v}$ velocity to a sensitive receiver, the received audio frequency is calculated by the receiver according to the transmitter's audio velocity using the following equation:

$$
\mathrm{F}_{\text {Doppler }}=-\mathrm{F}_{\text {Source }}\left(\frac{\mathrm{v}}{\mathrm{c}}\right)
$$

Where $F_{\text {Doppler }}$ is changing frequency of the received sound and $F_{\text {Source }}$ is transmitter sound frequency; $v$ is velocity of the transmitter to the receiver; $c$ is sound velocity in fluid, which is assumed to be $1484 \mathrm{~m} / \mathrm{s}$ in the present study.

Figure 6 shows that how the device is placed inside the stream, which begins to flow at a discharge of $10 \mathrm{l} / \mathrm{s}$ to $90 \mathrm{l} / \mathrm{s}$, and each discharge was taken for 2 minutes, and this discharge has been performed at all three angles of the channel.

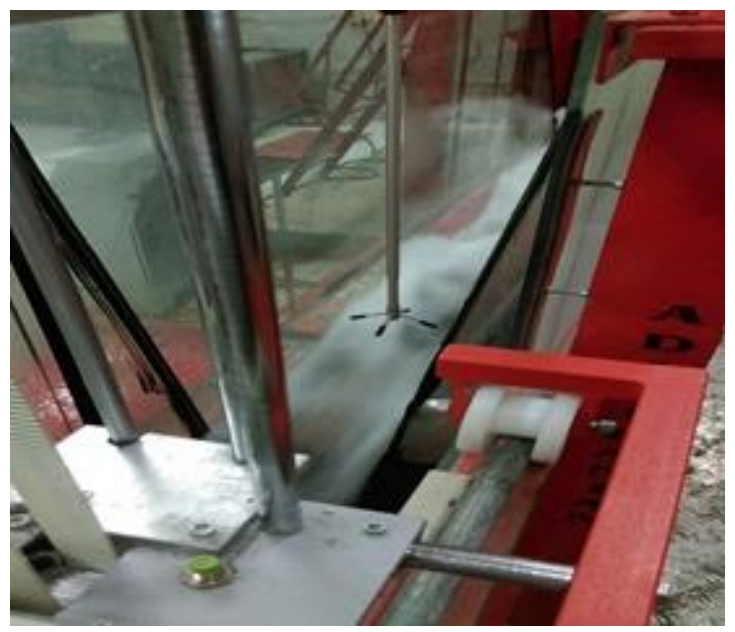


Tecnología y

Ciencias $\approx$ Agua
2019, Instituto Mexicano de Tecnología del Agua

Open Access, license CC BY-NC-SA 4.0

(https://creativecommons.org/licenses/by-nc$\mathrm{sa} / 4.0 /)$

Figure 6. How to put the device inside the stream.

In Figure 7, Figure 8 and Figure 9, the beginning of the hydraulic jump formed by the discharge of 90,70 and 50 lit/s at $75^{\circ}$ is shown.

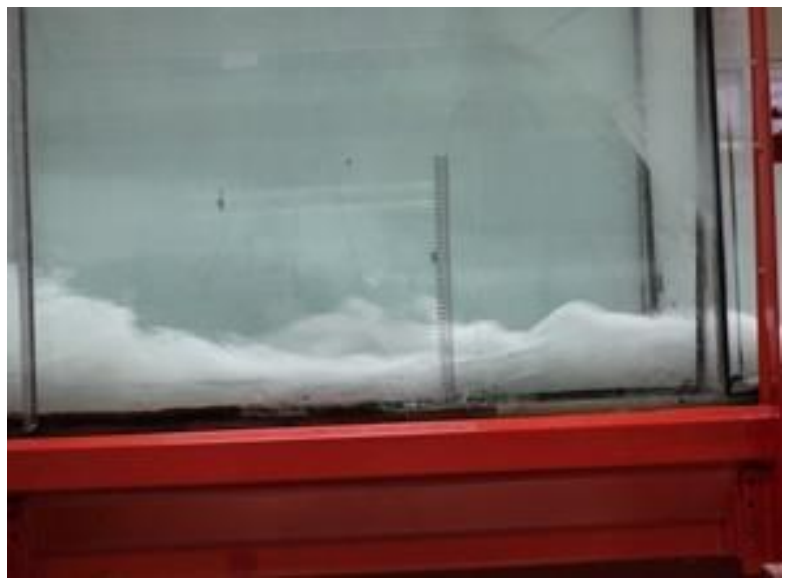

Figure 7. Beginning of hydraulic jump in 90lit/s.

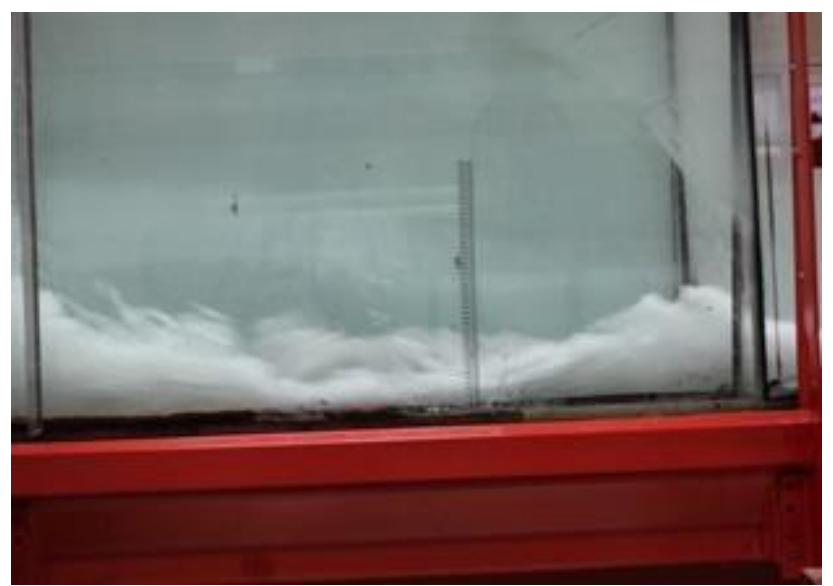

Figure 8. Beginning of hydraulic jump in $70 \mathrm{l} / \mathrm{s}$. 
Tecnología y

Ciencias 곰
2019, Instituto Mexicano de Tecnología del Agua

Open Access, license CC BY-NC-SA 4.0

(https://creativecommons.org/licenses/by-nc$\mathrm{sa} / 4.0 /$ )

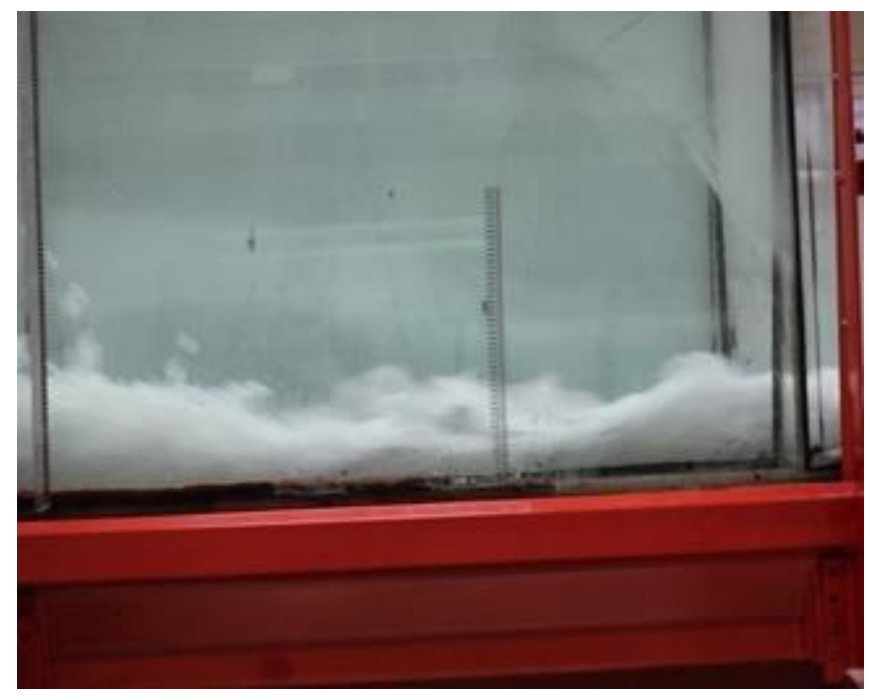

Figure 9. Beginning of hydraulic jump in $50 \mathrm{l} / \mathrm{s}$.

Table 3 and Table 4 present experimental and numerical results, respectively, and they illustrate five different discharges of 90, 70, 50, 30 and $10 \mathrm{l} / \mathrm{s}$. These tables also present the Froude numbers before and after the jump, the initial depth, and ratio of the jump length to the secondary depth for all three geometric sections, which is done to show non-dimensional of the jump length.

Table 3. Experimental results in three Trapezoidal sections.

\begin{tabular}{|c|c|c|c|c|c|c|c|c|c|c|}
\hline & & & \multicolumn{3}{|c|}{$\mathrm{m}=1.0$} & \multicolumn{3}{|c|}{$\mathrm{m}=0.58$} & \multicolumn{2}{|c|}{$m=0.26$} \\
\hline & & $\left(F_{r}\right)$ & $\mathrm{L}_{\mathrm{j}} / \mathrm{Y}_{2}$ & $\begin{array}{l}\text { Initial } \\
\text { depth } \\
(\mathrm{m})\end{array}$ & $\left(F_{r}\right)$ & $\mathrm{L}_{\mathrm{j}} / \mathrm{Y}_{2}$ & $\begin{array}{l}\text { Initial } \\
\text { depth } \\
(\mathrm{m})\end{array}$ & $\left(F_{r}\right)$ & $\mathrm{L}_{\mathrm{j}} / \mathrm{Y}_{2}$ & $\begin{array}{l}\text { Initial } \\
\text { depth } \\
(\mathrm{m})\end{array}$ \\
\hline \multirow{2}{*}{$\begin{array}{l}Q=90 \\
(\mathrm{l} / \mathrm{s})\end{array}$} & $\begin{array}{l}\text { Before } \\
\text { jump }\end{array}$ & 8.67 & \multirow[t]{2}{*}{6.18} & \multirow[t]{2}{*}{0.06} & 12.2 & \multirow[t]{2}{*}{6} & \multirow[t]{2}{*}{0.073} & 12 & \multirow[t]{2}{*}{5.11} & \multirow[t]{2}{*}{0.08} \\
\hline & $\begin{array}{l}\text { After } \\
\text { jump }\end{array}$ & 0.52 & & & 0.64 & & & 0.77 & & \\
\hline \multirow[t]{2}{*}{$\begin{array}{l}Q=70 \\
(\mathrm{l} / \mathrm{s})\end{array}$} & $\begin{array}{l}\text { Before } \\
\text { jump }\end{array}$ & 7.79 & \multirow[t]{2}{*}{6.13} & \multirow[t]{2}{*}{0.05} & 7 & \multirow[t]{2}{*}{5.9} & \multirow[t]{2}{*}{0.057} & 4 & \multirow[t]{2}{*}{6} & \multirow[t]{2}{*}{0.062} \\
\hline & $\begin{array}{l}\text { After } \\
\text { jump }\end{array}$ & 0.73 & & & 0.76 & & & 0.84 & & \\
\hline$Q=50$ & Before & 3.3 & 5.5 & 0.027 & 2.1 & 5.41 & 0.037 & 2.1 & 5.21 & 0.042 \\
\hline
\end{tabular}


2019, Instituto Mexicano de Tecnología del Agua

Open Access, license CC BY-NC-SA 4.0

Tecnología y

(https://creativecommons.org/licenses/by-nc-

$\mathrm{sa} / 4.0 /$ )

\begin{tabular}{|c|c|c|c|c|c|c|c|c|c|c|}
\hline \multirow{2}{*}{$(\mathrm{l} / \mathrm{s})$} & jump & & & & & & & & & \\
\hline & $\begin{array}{l}\text { After } \\
\text { jump }\end{array}$ & 0.36 & & & 0.63 & & & 0.81 & & \\
\hline \multirow{2}{*}{$\begin{array}{l}Q=30 \\
(/ \mathrm{s})\end{array}$} & $\begin{array}{l}\text { Before } \\
\text { jump }\end{array}$ & 2 & \multirow[t]{2}{*}{4} & \multirow[t]{2}{*}{0.024} & 1.86 & \multirow[t]{2}{*}{4.9} & \multirow[t]{2}{*}{0.03} & 1.1 & \multirow[t]{2}{*}{4.7} & \multirow[t]{2}{*}{0.038} \\
\hline & $\begin{array}{l}\text { After } \\
\text { jump }\end{array}$ & 0.28 & & & 0.31 & & & 0.38 & & \\
\hline \multirow[t]{2}{*}{$\begin{array}{l}Q=10 \\
(\mathrm{l} / \mathrm{s})\end{array}$} & $\begin{array}{l}\text { Before } \\
\text { jump }\end{array}$ & 1.2 & \multirow[t]{2}{*}{3.1} & \multirow[t]{2}{*}{0.025} & 1.1 & \multirow[t]{2}{*}{3.72} & \multirow[t]{2}{*}{0.031} & 1.2 & \multirow[t]{2}{*}{3.81} & \multirow[t]{2}{*}{0.033} \\
\hline & $\begin{array}{l}\text { After } \\
\text { jump }\end{array}$ & 0.13 & & & 0.17 & & & 0.16 & & \\
\hline
\end{tabular}

Table 4. Numerical results in three Trapezoidal sections.

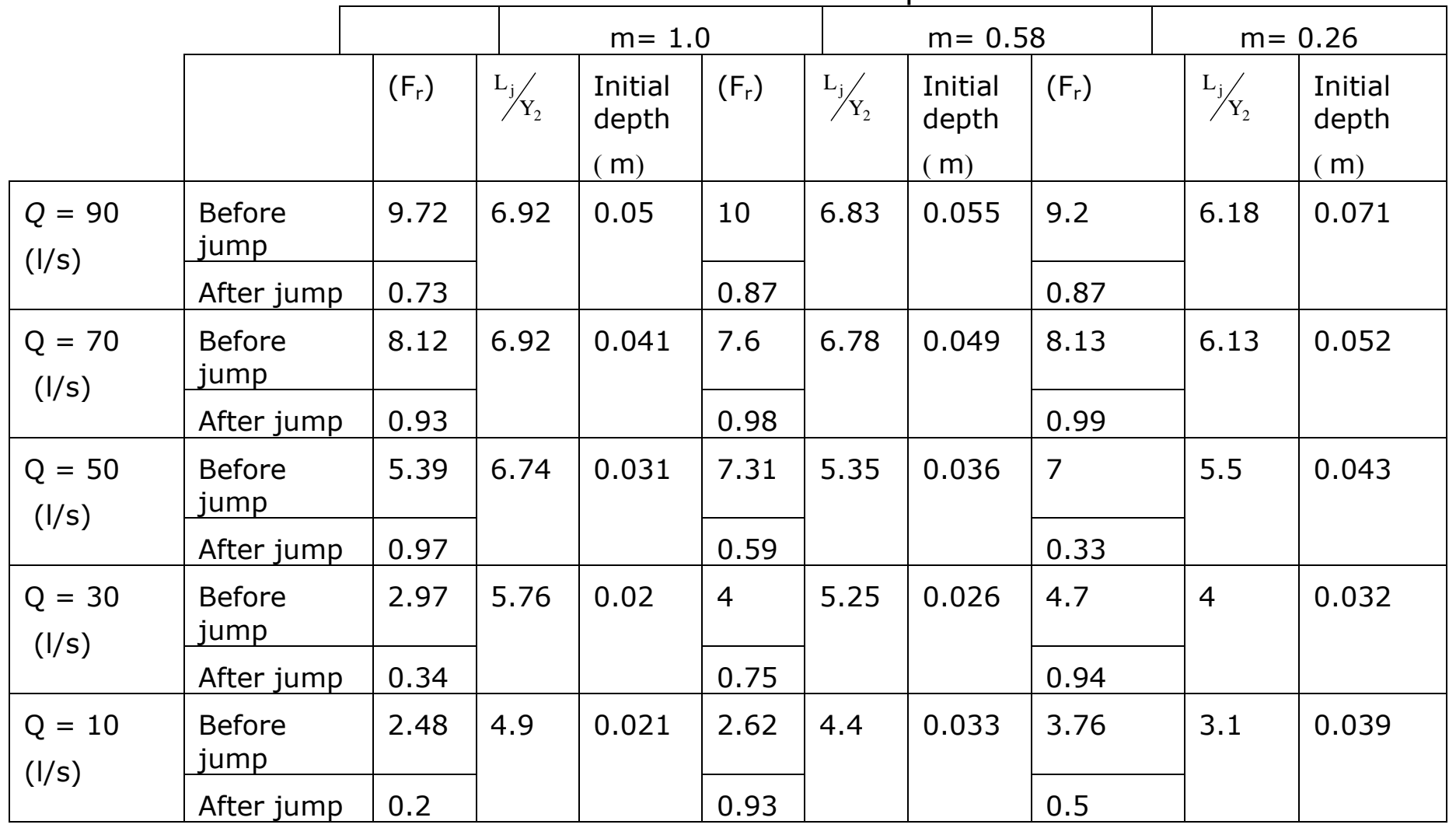

Figure 10a and Figure 10b depicts the dispersion of SNR and correlation, respectively, in secondary currents in the direction of perpendicular to the flow axis $\left(V_{x}\right)$ relative to the number of device impressions in the hydraulic jump. Figure $11 \mathrm{a}$ and Figure $11 \mathrm{~b}$, show the dispersion of SNR 
Tecnología y

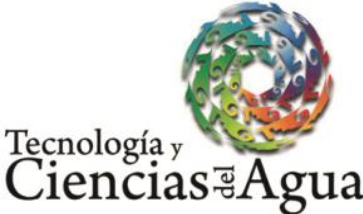

2019, Instituto Mexicano de Tecnología del Agua Open Access, license CC BY-NC-SA 4.0 (https://creativecommons.org/licenses/by-nc$\mathrm{sa} / 4.0 /$ )

and Correlation in secondary currents in the direction of perpendicular to the flow axis $\left(V_{z}\right)$ relative to the number of device impressions in the hydraulic jump. Concerning the Figure 10 and Figure 11, the correlation distribution at secondary currents velocities in the direction perpendicular to the axis $\left(V_{x}\right)$ of flow was greater than the secondary velocities in the direction of the perpendicular to the channel bed $\left(V_{z}\right)$. In high discharges, due to the higher flow velocity, the correlation mitigates in the direction perpendicular to the axis of flow $\left(V_{x}\right)$.
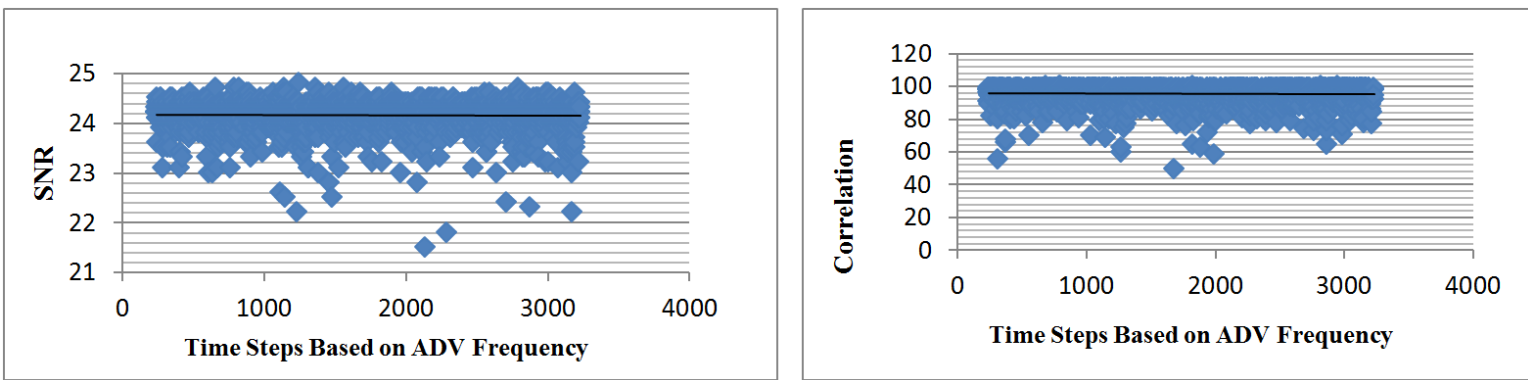

Figure 10. (a) The process of data acquisition changes based on the time steps of the ADV frequency relative to the SNR in secondary currents in the direction $V_{x}$; (b) The process of data acquisition changes based on the time steps of the ADV frequency relative to the Signal Correlation in secondary currents in the direction $V_{x}$.
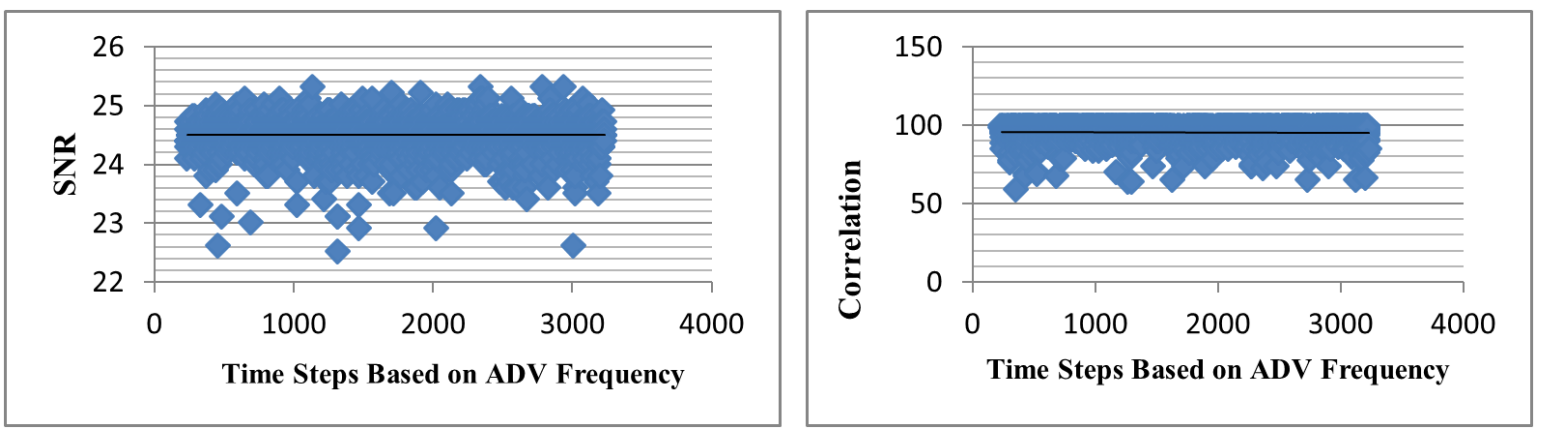

Figure 11. (a) The process of data acquisition changes based on the time steps of the ADV frequency relative to the SNR in secondary currents in the direction $V_{z}$; (b) The process of data acquisition changes based on the time steps of the ADV frequency relative to the Signal Correlation in secondary currents in the direction $V_{z}$.

The velocity distribution trend in the horizontal direction $(x)$ was higher in channels with less sidewall slopes, such as those with the $45^{\circ}$ angle. The flow velocity is also higher in the horizontal direction $(x)$ and therefore it leads to development of shear stress in the channels and 
Tecnología y

Ciencias $\approx$ Agua
2019, Instituto Mexicano de Tecnología del Agua Open Access, license CC BY-NC-SA 4.0

(https://creativecommons.org/licenses/by-nc$\mathrm{sa} / 4.0 /$ )

eventually it reduces the hydraulic jump energy in the channel geometry, which in effect has a greater effect on higher discharges. In line with the objectives of this research and to investigate the secondary current cells in the horizontal direction $(x)$, two high discharges, namely, $90 \mathrm{l} / \mathrm{s}$ and 70 lit/s were scrutinized. Discharges below these values do not dramatically affect the jump energy loss in secondary current cells within the horizontal direction $(x)$. With increases in the flow velocity along channel $(y)$, the velocity of secondary currents in $x$-direction increases more at $45^{\circ}$ angle, compared to $60^{\circ}$ and $75^{\circ}$ angles.

In contrast, velocity vector distribution of secondary currents perpendicular to the flow surface $(z)$ in the weaker discharge is greater than that of the side walls, due to the low flow velocity and the dominance of the gravity distribution velocity to the channel floor. This is the case in the velocity values of secondary flows in each of the three sections shown in Table 5 associated with experimental tests and Table 6 related to numerical modeling. As shown in Table 5 and Table 6, the velocity values are in the horizontal direction $(x)$ for high discharges, and the values for the 45 and $60^{\circ}$ angles section are in the vertical direction. Furthermore, velocity of the secondary currents in the vertical direction $(z)$ for low discharges at 60 and $75^{\circ}$ angles were greater than that of secondary currents in the horizontal direction $(x)$.

Table 5. Experimental Secondary currents flow velocities in $x$ and $z$ direct.

\begin{tabular}{|c|c|c|c|c|}
\hline Row & $Q(1 / 5)$ & $m=1.0$ & $m=0.58$ & $m=0.26$ \\
\hline \multirow[t]{2}{*}{1} & \multirow[t]{2}{*}{90} & $V_{x}=0.36 \mathrm{~m} / \mathrm{s}$ & $V_{x}=0.31 \mathrm{~m} / \mathrm{s}$ & $V_{x}=0.26 \mathrm{~m} / \mathrm{s}$ \\
\hline & & $V_{z}=0.22 \mathrm{~m} / \mathrm{s}$ & $V_{z}=0.25 \mathrm{~m} / \mathrm{s}$ & $V_{z}=0.27 \mathrm{~m} / \mathrm{s}$ \\
\hline \multirow[t]{2}{*}{2} & \multirow[t]{2}{*}{70} & $V_{x}=0.33 \mathrm{~m} / \mathrm{s}$ & $V_{x}=0.18 \mathrm{~m} / \mathrm{s}$ & $V_{x}=0.15 \mathrm{~m} / \mathrm{s}$ \\
\hline & & $V_{z}=0.26 \mathrm{~m} / \mathrm{s}$ & $V_{z}=0.29 \mathrm{~m} / \mathrm{s}$ & $V_{z}=0.49 \mathrm{~m} / \mathrm{s}$ \\
\hline \multirow[t]{2}{*}{3} & \multirow[t]{2}{*}{50} & $V_{x}=0.21 \mathrm{~m} / \mathrm{s}$ & $V_{x}=0.16 \mathrm{~m} / \mathrm{s}$ & $V_{x}=0.11 \mathrm{~m} / \mathrm{s}$ \\
\hline & & $V_{z}=0.39 \mathrm{~m} / \mathrm{s}$ & $V_{z}=0.5 \mathrm{~m} / \mathrm{s}$ & $V_{z}=0.6 \mathrm{~m} / \mathrm{s}$ \\
\hline \multirow[t]{2}{*}{4} & \multirow[t]{2}{*}{30} & $V_{x}=0.14 \mathrm{~m} / \mathrm{s}$ & $V_{x}=0.1 \mathrm{~m} / \mathrm{s}$ & $V_{x}=0.07 \mathrm{~m} / \mathrm{s}$ \\
\hline & & $V_{z}=0.41 \mathrm{~m} / \mathrm{s}$ & $V_{z}=0.52 \mathrm{~m} / \mathrm{s}$ & $V_{z}=0.81 \mathrm{~m} / \mathrm{s}$ \\
\hline \multirow[t]{2}{*}{5} & \multirow[t]{2}{*}{10} & $V_{x}=0.11 \mathrm{~m} / \mathrm{s}$ & $V_{x}=0.05 \mathrm{~m} / \mathrm{s}$ & $V_{x}=0.01 \mathrm{~m} / \mathrm{s}$ \\
\hline & & $V_{z}=0.49 \mathrm{~m} / \mathrm{s}$ & $V_{z}=0.61 \mathrm{~m} / \mathrm{s}$ & $V_{z}=0.92 \mathrm{~m} / \mathrm{s}$ \\
\hline
\end{tabular}


Tecnología y

Ciencias $₫$ Angua
2019, Instituto Mexicano de Tecnología del Agua Open Access, license CC BY-NC-SA 4.0 (https://creativecommons.org/licenses/by-nc$\mathrm{sa} / 4.0 /$ )

Table 6. Numerical Secondary currents flow velocities in $x$ and $z$ direct.

\begin{tabular}{|l|l|l|l|l|}
\hline Row & Q (I/s) & \multicolumn{1}{c|}{$\boldsymbol{m}=\mathbf{1 . 0}$} & \multicolumn{1}{c|}{$\boldsymbol{m}=\mathbf{0 . 5 8}$} & \multicolumn{1}{c|}{$\boldsymbol{m}=\mathbf{0 . 2 6}$} \\
\hline \multirow{2}{*}{1} & \multirow{2}{*}{90} & $V_{x}=0.39 \mathrm{~m} / \mathrm{s}$ & $V_{x}=0.35 \mathrm{~m} / \mathrm{s}$ & $V_{x}=0.29 \mathrm{~m} / \mathrm{s}$ \\
\cline { 3 - 5 } & & $V_{z}=0.19 \mathrm{~m} / \mathrm{s}$ & $V_{z}=0.23 \mathrm{~m} / \mathrm{s}$ & $V_{z}=0.25 \mathrm{~m} / \mathrm{s}$ \\
\hline \multirow{2}{*}{2} & \multirow{2}{*}{30} & $V_{x}=0.36 \mathrm{~m} / \mathrm{s}$ & $V_{x}=0.21 \mathrm{~m} / \mathrm{s}$ & $V_{x}=0.17 \mathrm{~m} / \mathrm{s}$ \\
\cline { 3 - 5 } & \multirow{2}{*}{3} & $V_{z}=0.24 \mathrm{~m} / \mathrm{s}$ & $V_{z}=0.27 \mathrm{~m} / \mathrm{s}$ & $V_{z}=0.46 \mathrm{~m} / \mathrm{s}$ \\
\hline \multirow{2}{*}{4} & \multirow{2}{*}{30} & $V_{x}=0.25 \mathrm{~m} / \mathrm{s}$ & $V_{x}=0.18 \mathrm{~m} / \mathrm{s}$ & $V_{x}=0.15 \mathrm{~m} / \mathrm{s}$ \\
\cline { 3 - 5 } & & $V_{z}=0.35 \mathrm{~m} / \mathrm{s}$ & $V_{z}=0.46 \mathrm{~m} / \mathrm{s}$ & $V_{z}=0.57 \mathrm{~m} / \mathrm{s}$ \\
\hline \multirow{2}{*}{5} & \multirow{2}{*}{10} & $V_{x}=0.16 \mathrm{~m} / \mathrm{s}$ & $V_{x}=0.13 \mathrm{~m} / \mathrm{s}$ & $V_{x}=0.1 \mathrm{~m} / \mathrm{s}$ \\
\cline { 3 - 5 } & & $V_{x}=0.36 \mathrm{~m} / \mathrm{s}$ & $V_{z}=0.47 \mathrm{~m} / \mathrm{s}$ & $V_{z}=0.76 \mathrm{~m} / \mathrm{s}$ \\
\cline { 3 - 5 } & & $V_{z}=0.41 \mathrm{~m} / \mathrm{s}$ & $V_{x}=0.11 \mathrm{~m} / \mathrm{s}$ & $V_{x}=0.05 \mathrm{~m} / \mathrm{s}$ \\
\hline
\end{tabular}

Figure 12 illustrates variation in velocity of the secondary current in the direction of the vertical flow axis $\left(V_{x}\right)$, which is plotted with changes in Froude numbers. Velocity of the secondary current cells for the crosssectional of $45^{\circ}$ angle in $x$-direction at different Froude number rates (Figure 12), was greater than the velocity of other sections in both experimental tests and numerical modeling. It can be concluded that the shear stress created in the side walls of this section is greater than the shear stress created in the other sections, which leads the flow towards the side walls. Figure 12 illustrates variation in the velocity of the secondary currents as shown in vertical direction $\left(V_{z}\right)$ relative to the Froude number. The results show the trend to be opposite the horizontal $\left(V_{x}\right)$ direction. Figure 13 illustrates changes in the velocity of the secondary currents, as shown in vertical direction $\left(V_{z}\right)$ relative to the Froude number. The results show the trend to be opposite the horizontal $\left(V_{x}\right)$ direction. 


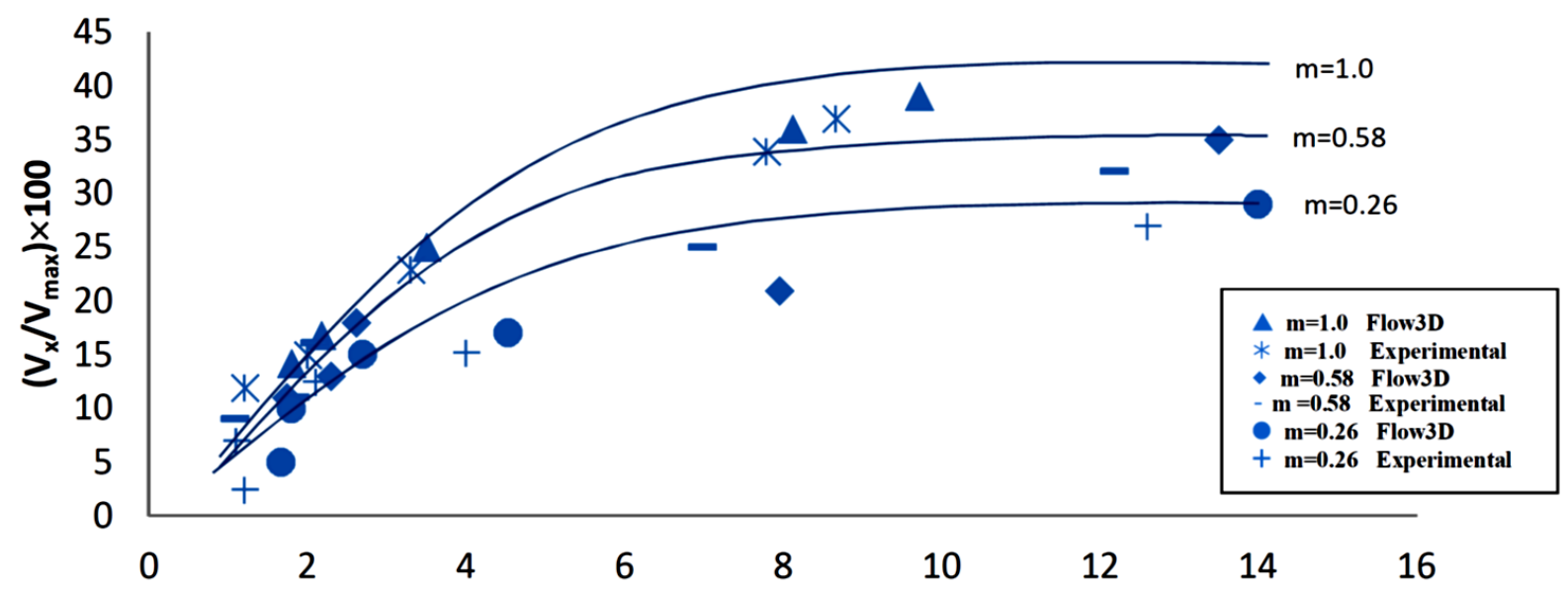

Froude number $\left(\mathrm{Fr}_{1}\right)$

Figure 12. Comparison of secondary currents velocity in horizontal direct $\left(V_{x}\right)$ with function of $F_{1}$ for various $\mathrm{m}$ in Flow3-D and experimental tests.

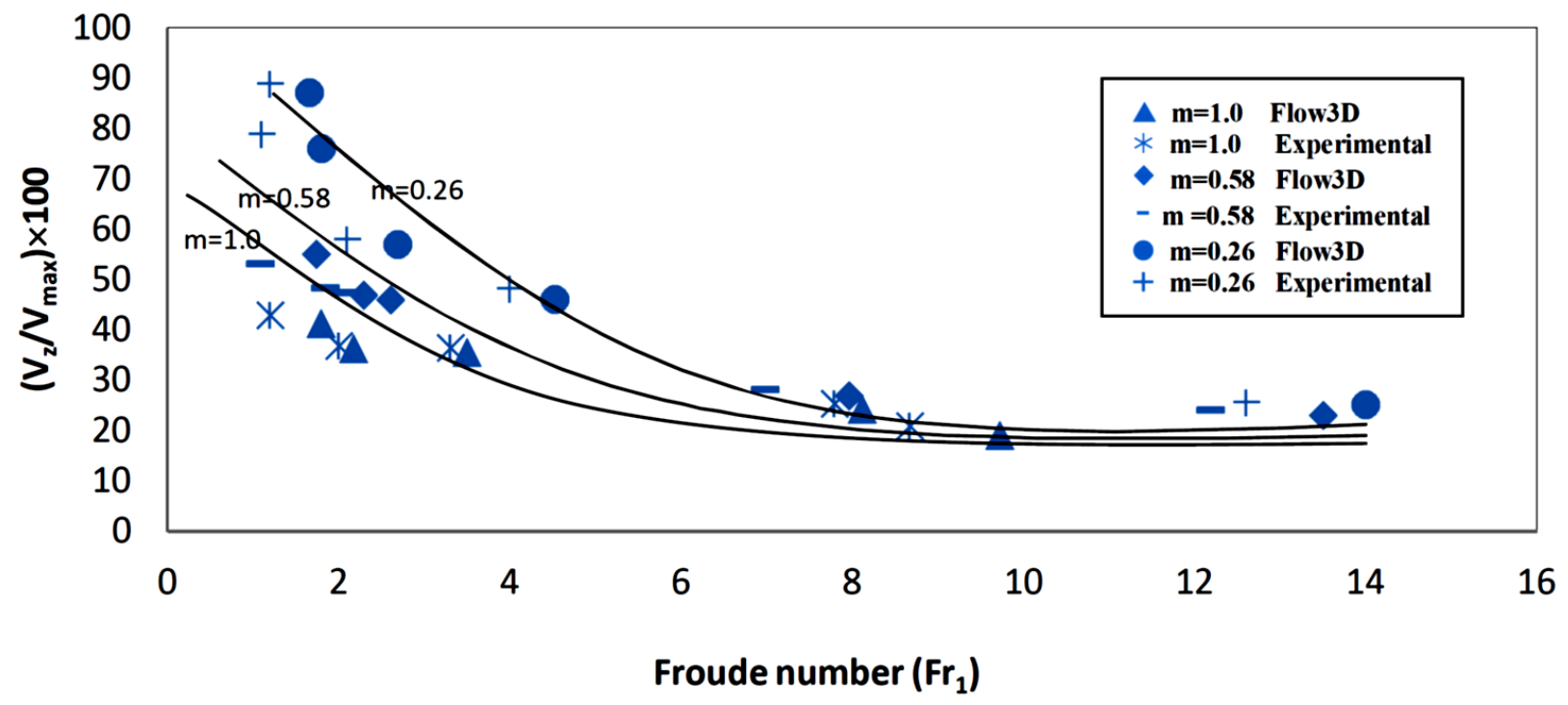

Figure 13. Comparison of secondary current velocity in vertical direction $\left(V_{z}\right)$ with function of $F_{1}$ for various $m$ in Flow3-D and experimental tests.

According to the results of Figure 12, the equations governing the process of variation of the secondary currents velocity in the horizontal 
Tecnología y

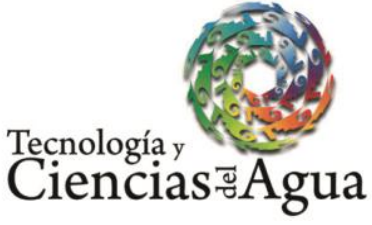

2019, Instituto Mexicano de Tecnología del Agua Open Access, license CC BY-NC-SA 4.0 (https://creativecommons.org/licenses/by-nc$\mathrm{sa} / 4.0 /)$

direction $\left(V_{x}\right)$ versus the Froude number for each of the three sections follow the following relationships:

$$
\begin{array}{ll}
\text { For } \mathrm{m}=1.0 & (\mathrm{Vx} / \mathrm{Vmax}) \times 100=13.6 \ln (\mathrm{Fr} 1)+7.1 \\
\mathrm{~m}=0.58 & (\mathrm{Vx} / \mathrm{Vmax}) \times 100=9.6 \ln (\mathrm{Fr} 1)+6.6 \\
\mathrm{~m}=0.26 & \left(\mathrm{Vx} / \mathrm{Vmax}_{\max }\right) \times 100=9.4 \ln (\mathrm{Fr} 1)+3.4
\end{array}
$$

Moreover according to the results of Figure 13, the equations governing the process of variation of the secondary currents velocity in the vertical direction $\left(V_{z}\right)$ versus the Froude number for each of the three sections follow the following relationships:

For $\mathrm{m}=1.0 \quad(V z / V \max ) \times 100=-11 \ln (F r 1)+46.4$

$\mathrm{m}=0.58\left(\mathrm{Vz} / \mathrm{Vmax}_{\max }\right) \times 100=-14 \ln (F r 1)+57.7$

$\mathrm{m}=0.26\left(V z / V_{\max }\right) \times 100=-24.8 \ln (F r 1)+86.8$

Velocity increases in horizontal directions when the cross-sectional changes from 75 to $45^{\circ}$ angles in high Froude numbers. It is also possible to increase the vertical velocity $\left(V_{z}\right)$ by changing the crosssectional from 45 to $75^{\circ}$ angles, in low Froude numbers. According to the data presented by Figure 12 and Figure 13, and Table 5 and Table 6, rough $33 \%$ and $28.9 \%$ growth rates can be obtained in a horizontal direction $\left(V_{x}\right)$ of $75^{\circ}$ to $60^{\circ}$ angles in experimental tests, and in the same situation in numerical modeling, respectively, while about $44 \%$ at 60 to $45^{\circ}$ angles in experimental tests and $32.6 \%$ in the same situation in numerical modeling can be obtained. Secondary velocity currents in vertical directions $\left(V_{z}\right)$ were increased by $22.5 \%$ from 45 to $60^{\circ}$ angles during experimental tests, while the currents were increased by $28 \%$ during numerical modeling, and they were increased by $42 \%$ from 60 to $75^{\circ}$ angles during experimental tests. Moreover, the currents were increased by $47 \%$ during numerical modeling. The results of the data of Table 5 and Table 6 were compared using the root mean square error (RMSE) and determination coefficient (DC), which is calculated using 
Tecnología y

Ciencias $\approx$ Agua
2019, Instituto Mexicano de Tecnología del Agua

Open Access, license CC BY-NC-SA 4.0

(https://creativecommons.org/licenses/by-nc$\mathrm{sa} / 4.0 /$ )

following two relationships. The results are given in Table 7, and it can be deduced that, the maximum effect of secondary current velocity emerged in the horizontal direction $\left(V_{x}\right)$ at $45^{\circ}$ degree, and the maximum effect of secondary current velocity were in vertical direction $\left(V_{z}\right)$ at $75^{\circ}$ angle:

$$
\begin{aligned}
& \text { RMSE }=\sqrt{\frac{1}{N}\left(\sum S_{n}-\widehat{S}_{n}\right)^{2}} \\
& D C=1-\frac{\sum\left(S_{n}-\hat{S}_{n}\right)^{2}}{\sum\left(S_{n}-\overline{S_{n}}\right)^{2}}
\end{aligned}
$$

Table 7. Results of RMSE and DC for three geometry sections.

\begin{tabular}{|l|l|l|l|l|}
\hline & \multicolumn{2}{|c|}{$\boldsymbol{V}_{\mathbf{z}}$} & \multicolumn{2}{c|}{ RMSE } \\
\hline $\begin{array}{c}\text { Type of trapezoidal } \\
\text { channel }\end{array}$ & \multicolumn{1}{|c|}{ DC } & \multicolumn{1}{c|}{ DC } & \multicolumn{1}{c|}{ RMSE } \\
\hline$m=1.0$ & 0.77 & 0.098 & $\mathbf{0 . 9 1}$ & $\mathbf{0 . 0 6 7}$ \\
\hline$m=0.58$ & 0.89 & 0.084 & 0.82 & 0.08 \\
\hline$m=0.26$ & $\mathbf{0 . 9 5}$ & $\mathbf{0 . 0 8}$ & 0.85 & 0.07 \\
\hline
\end{tabular}

The range of the DC is between 0 and 1 and as its value approaches toward 1 , the situation gets the desirable. The value of the R.M.S.E is closer to the number 0 as it is. Therefore, the numbers 0.91 and 0.067 for the secondary currents velocity in the horizontal direction $\left(V_{x}\right)$ and 0.95 and 0.08 for the secondary currents velocity in the vertical direction $\left(V_{z}\right)$ are the best possible values for reaching to the desirable results. Figure 14 shows the sequent depths ratio $Y_{2} / Y_{1}$ as a functions of $F_{1}$ for various $(\mathrm{m})$ in both numerical modeling and experimental tests which was compared with the experimental results obtained by Hager (1992). Figure 15 illustrates comparison of hydraulic jump length $L_{j} / Y_{1}$ as a function of $F_{1}$ for various $(m)$ in present work and it was compared with the experimental results of Hager (1992). Figure 16 shows the variations of relative energy loss in a hydraulic jump. In Figure 16, the energy loss in the models performed is shown below the Froude number changes. It is evident that, in both numerical modeling and experimental tests the energy loss in trapezoidal sections with a lateral angle $45^{\circ}$ angle was significant, compared to the other two sections with 
increasing Froude number. The obtained results were compared with that of Hager (1992) for better validation of the data for this energy loss chart in each of the three sections of this study.

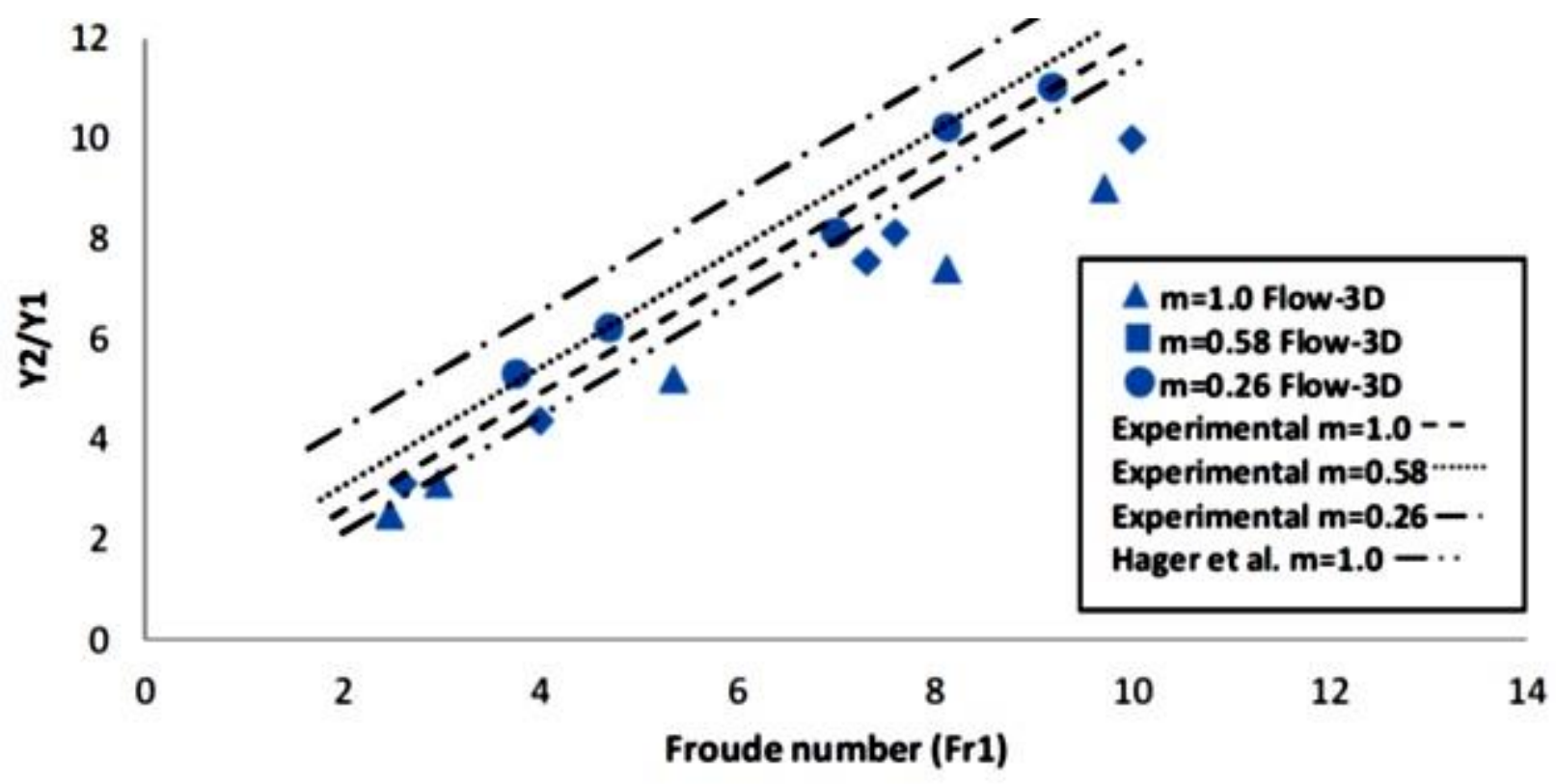

Figure 14. Sequent depths ratio $\left(Y_{2} / Y_{1}\right)$ as a functions of $F_{1}$ for various $m$ in Flow3-D and experimental tests. 
Tecnología y

Ciencias $\stackrel{\mho}{\triangleleft}$ gua
2019, Instituto Mexicano de Tecnología del Agua

Open Access, license CC BY-NC-SA 4.0

(https://creativecommons.org/licenses/by-nc$\mathrm{sa} / 4.0 /$ )

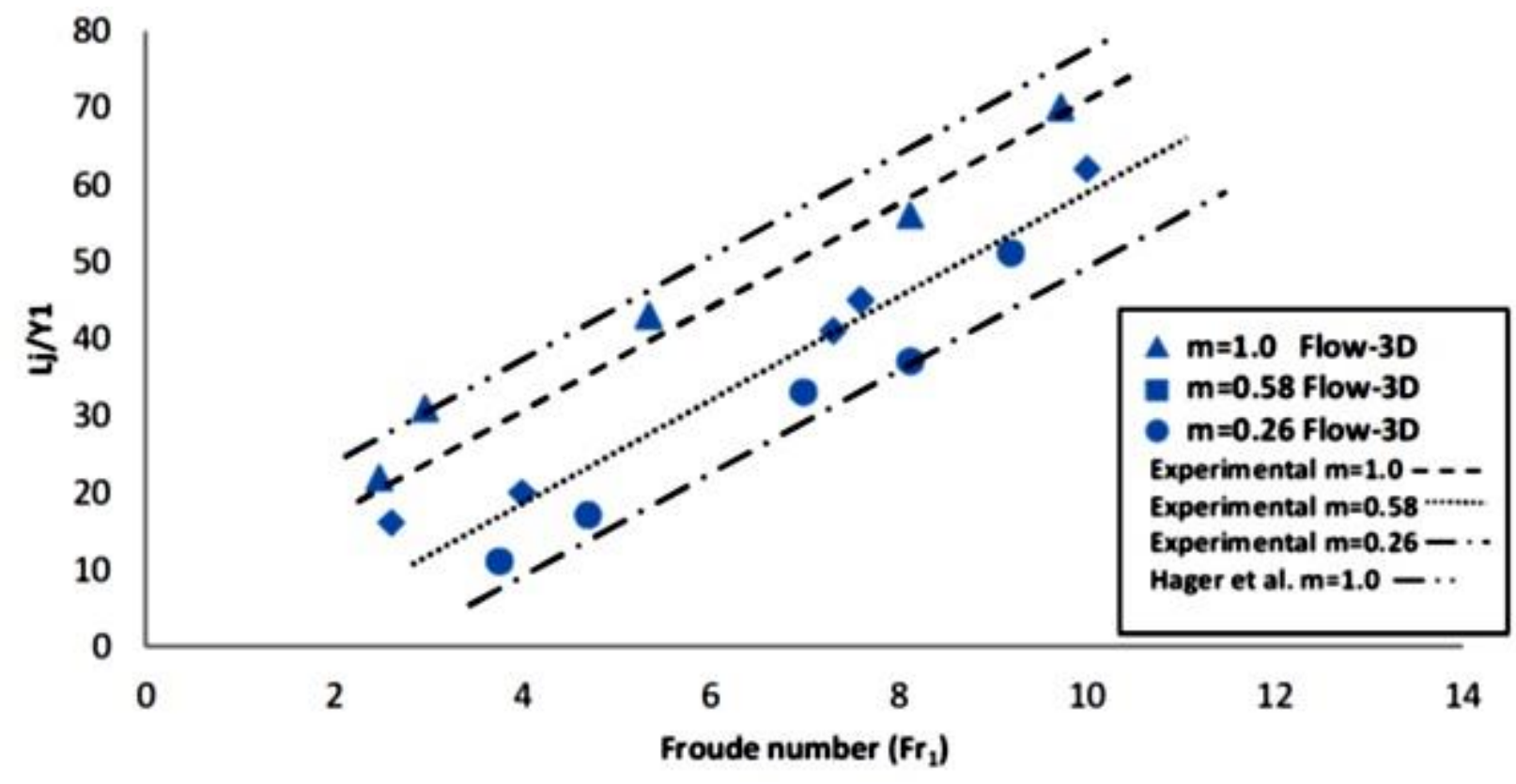

Figure 15. The ratio of the hydraulic jump length to the initial depth $\left(L_{j} / Y_{1}\right)$ as a function of $F_{1}$ for various $m$ in Flow3$D$ and experimental tests.

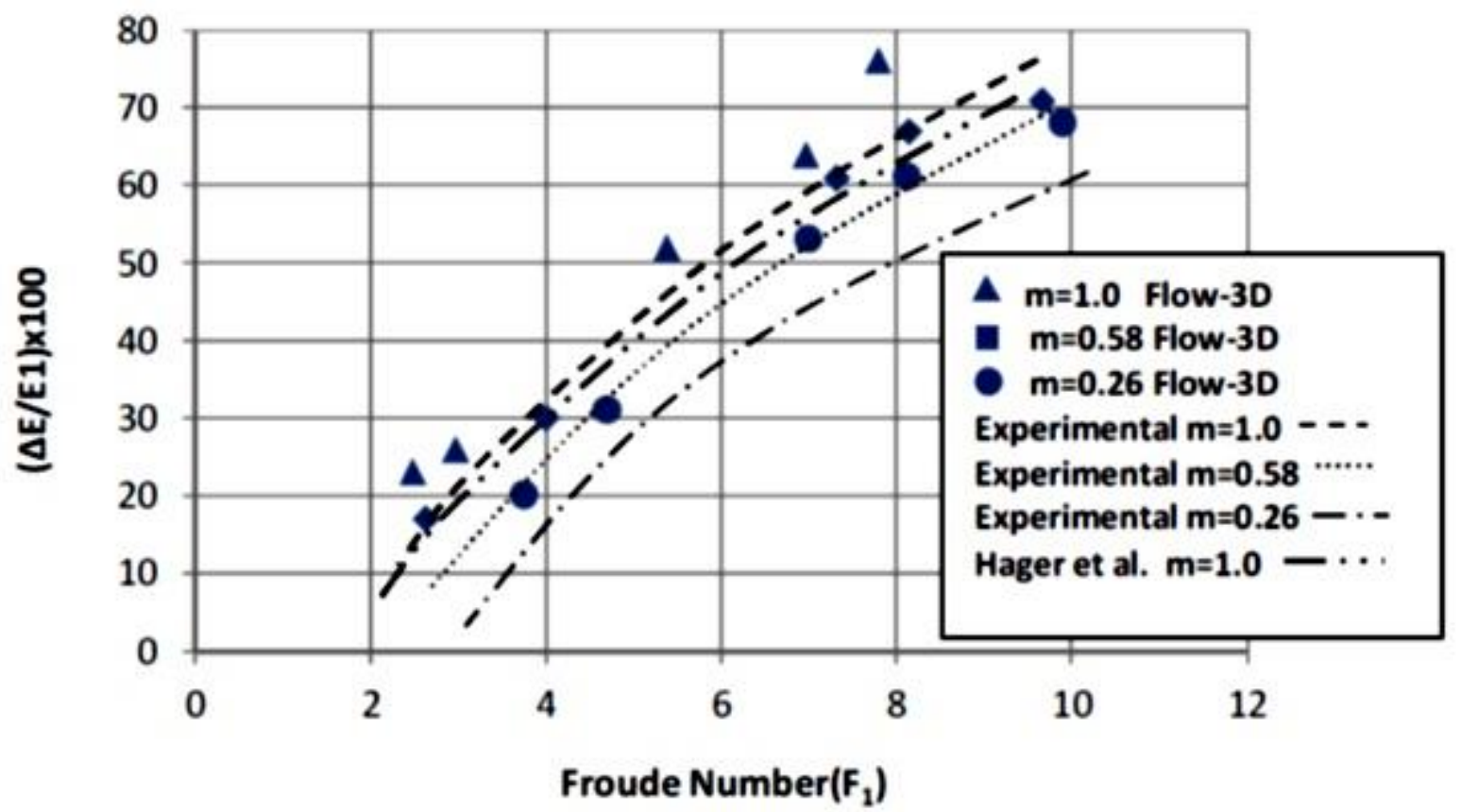


Tecnología y

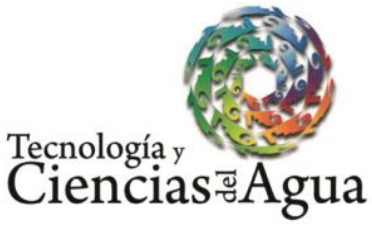

2019, Instituto Mexicano de Tecnología del Agua Open Access, license CC BY-NC-SA 4.0

(https://creativecommons.org/licenses/by-ncsa/4.0/)

Figure 16. Comparison of relative energy loss in hydraulic jump as function of $F_{1}$ for various $m$ in Flow3-D models and experimental tests.

About Figure 15, the length of hydraulic jump in both numerical models and experimental tests at $45^{\circ}$ angle has been increased with the increase in landing number, compared to the other two sections.

As shown in Figure 16, the energy loss in hydraulic jump at $45^{\circ}$ angle cross section during experimental tests exhibited an increase of $4 \%$, compared to Hager's results. Also, during numerical modeling at $45^{\circ}$ angle, an increase of $9 \%$ in comparison with Hager's results, was spotted. Generally speaking, these results indicate verification of the numerical and experimental tests. According to the comparison made between the results of numerical modeling and experimental tests, there is a desirable agreement between the results of these two models in all three geometric sections. So that, at $45^{\circ}$ angle in the numerical models there is $5 \%$ increase compared to the experimental tests, and at $60^{\circ}$ angle in the numerical models there is $11 \%$ increase compared to the experimental tests, and also at $75^{\circ}$ angle in the numerical models there is $14 \%$ increase compared to the experimental tests. So that, the highest increase can be attributed to $45^{\circ}$ section.

\section{Conclusion}

1. The boundary conditions used in this study are very effective in determining the boundaries of computations and sensitivities.

2. The velocity of secondary currents perpendicular to the axis of flow $\left(V_{x}\right)$ in Froude number 10 of $45^{\circ}$ angle is higher than the two other sections, which is $71 \%$ compared to $75^{\circ}$ angle in numerical models and in Froude number 9 it was $91 \%$ in experimental tests.

3 . The velocity of the secondary currents in the vertical direction of the flow surface $\left(V_{z}\right)$ in Froude number 2 of $75^{\circ}$ angle is higher than the two other sections, which is $88 \%$ compared to the $45^{\circ}$ angle in numerical models and in Froude number 1.5 it was $74.5 \%$ in experimental tests. 
4. The results demonstrated the existence of an inverse relationship between the velocity of the secondary current in the direction of the vertical axis of the flow $\left(V_{x}\right)$ and the secondary velocity in the direction of the flow surface $\left(V_{z}\right)$ during both numerical models and experimental tests.

\section{Conflict of interest}

The authors declare that they have no conflict of interest.

\section{Nomenclature}

$b$

$Q$

$L_{j}$

W

V

$\vartheta$

$\overline{V^{2}}$

$\overline{W^{2}}$

$V_{x}$

$V_{z}$

$\vec{\nabla}$

$i, j, k$

$U$

$\dot{S}_{1}, \dot{S}_{2}$

$S_{1}, S_{2}$

$N_{1}, N_{2}$

$m$

$\mathrm{Fr}_{1}$

$Y_{2}$ is base width $(\mathrm{m})$.

is discharge $(\mathrm{l} / \mathrm{s})$.

is length of hydraulic jump (m).

is velocity components in horizontal direction $(\mathrm{m} / \mathrm{s})$.

is velocity components in vertical direction $(\mathrm{m} / \mathrm{s})$.

is kinematic viscosity $\left(\mathrm{m}^{2} / \mathrm{s}\right)$.

denotes Reynolds normal stress (vertical).

denotes Reynolds normal stress (horizontal).

is velocity of secondary currents in horizontal direction $(\mathrm{m} / \mathrm{s})$.

is velocity of secondary currents in vertical direction $(\mathrm{m} / \mathrm{s})$.

is nebula operator.

are unit coordinate vectors.

is velocity in curl function.

is return signals from two adjacent pulses.

are coherent part of the signal.

are random noise.

is cotangent of side slope.

is Froude number before hydraulic jump.

is secondary depth of hydraulic jump (m). 
Tecnología y

Ciencias $₫$ Angua
2019, Instituto Mexicano de Tecnología del Agua Open Access, license CC BY-NC-SA 4.0

(https://creativecommons.org/licenses/by-nc$\mathrm{sa} / 4.0 /$ )
SNR

$Y_{2} / Y_{1}$

$E_{1} / \Delta E$

RMSE

DC

C

$\checkmark$

$\Psi$

$F_{\text {Doppler }}$

$F_{\text {Source }}$ is signal noise ratio.

is sequent depth ratio.

is relative energy loss of hydraulic jump.

is root-mean-square-error.

is determination coefficient.

is velocity of sound $(\mathrm{m} / \mathrm{s})$.

is velocity of transmitter to the receiver $(\mathrm{m} / \mathrm{s})$.

is function of flow.

is changing frequency of the received sound.

is transmitter sound frequency.

\section{References}

Afzal, N., \& Bushra, A. (2002). Structure of the turbulent hydraulic jump in a trapezoidal channel. Journal of Hydraulic Research, 40(2), 205-214.

Azhdari-Moghaddam, M., Tajnasaj, M., \& Givech, M. (2013). Using computational fluid dynamic in numerical modeling of secondary currents in trapezoidal channels. Journal of Civil EngineeringFerdowsi (in Persian), 25(1), 15-28.

Bayon, A., Valero, D., García-Bartual, R., \& López-Jiménez, P. A. (2016). Performance assessment of OpenFOAM and FLOW-3D in the numerical modeling of a low Reynolds number hydraulic jump. Environmental Modelling \& Software, 80, 322-335.

Chanson, H. (2007). Bubbly flow structure in hydraulic jump. European Journal of Mechanics B, Fluids, 26(3), 367-384.

Nortek-AS. (2013). Comprehensive manual. Vangkroken, Norway: Nortek-AS.

Dasgupta, R., \& Tomar, G. (2015). Viscous undular hydraulic jumps of moderate Reynolds Number Flow. Procedia IUTAM, 15, 300-304.

Gupta, S. K., Mehta, R. C., \& Dwivedi, V. K. (2013). Modeling of relative length and relative energy loss of free hydraulic jump in horizontal prismatic channel. Procedia Engineering, 51, 529-537.

Hager, W. H. (1992). Energy dissipators and hydraulic jump (Vol. 8). Berlin, Germany: Springer Science \& Business Media. 
Tecnología y

Ciencias $₫$ Agua
2019, Instituto Mexicano de Tecnología del Agua Open Access, license CC BY-NC-SA 4.0 (https://creativecommons.org/licenses/by-nc$\mathrm{sa} / 4.0 /$ )

Jalili-Ghazizadeh, M., Attari, J., \& Farhadi-Rad, S. (January, 2017). Study of flow and hydraulic jump alongside weirs. In: Proceedings of the Institution of Civil Engineers-Water Management, 171(3), 134-142, Thomas Telford Ltd.

Javan, M., \& Eghbalzadeh, A. (2013). 2D numerical simulation of submerged hydraulic jumps. Applied Mathematical Modelling, 37(10-11), 6661-6669.

Kim, Y., Choi, G., Park, H., \& Byeon, S. (2015). Hydraulic jump and energy dissipation with sluice gate. Water, 7(9), 5115-5133.

Martin, V., Fisher, T. S. R., Millar, R. G., \& Quick, M. C. (2002). ADV data analysis for turbulent flows: Low correlation problem. In: Hydraulic Measurements and Experimental Methods Specialty Conference (HMEM) 2002 (pp. 1-10), DOI: $10.1061 / 40655(2002) 101$

Microsoft Corporation. (2015). GDI Generic. Flow-3D User Manual Version 11.1.1. Washington, DC, USA: Microsoft Corporation.

Muhsun, S. S. (2012). Characteristics of the hydraulic jump in trapezoidal channel section. Journal of Environmental Studies, 9, 53-62.

Nezu, I., Nakagawa, H., \& Tominaga, A. (1985). Secondary currents in a straight channel flow and the relation to its aspect ratio. In: Turbulent Shear Flows 4 (pp. 246-260). Springer, Berlin, Heidelberg.

Ohtsu, I. (1976, February). Free hydraulic jump and submerged hydraulic jump in trapezoidal and rectangular channels. In: Proceedings of the Japan Society of Civil Engineers, 1976(246), 57-72, Japan Society of Civil Engineers.

Prandtl, L. (1904). On fluid motions with very small friction. Verh/dg, 3, 484-491.

Qin, C., Shao, X., \& Zhou, G. (2016). Comparison of two different secondary flow correction models for depth-averaged flow simulation of meandering channels. Procedia Engineering, 154, 412-419.

Shokrian-Hajibehzad, M., \& Shafai-Bejestan, M. (2017, January). Predicting the sequent depth ratio of a BF hydraulic jump on a river-bed rock chute. In: Proceedings of the Institution of Civil 
Engineers-Water Management, 171(3), 143-151, Thomas Telford Ltd.

Wanoschek, R., \& Hager, W. H. (1989). Hydraulic jump in trapezoidal channel. Journal of Hydraulic Research, 27(3), 429-446.

Yaaghoubi, M., \& Givechi, M. (2007). The effect of secondary currents on the estimation of moderate depth in rectangular channels. In: Water Resources Conference, Conference Held at University of Sistan and Baluchestan, Zahedan, Iran. 